\title{
ADAK SAMPULONRUA \\ (STUDI FALSAFAH HIDUP MASYARAKAT MUSLIM BULUTTANA KECAMATAN TINGGIMONCONG KABUPATEN GOWA)
}

\author{
Ibrahim \\ Dosen Aqidah dan Filsafat Islam \\ Fakultas Usuludddin, Filsafat dan Politik \\ UIN Alaudddin Makassar \\ E-mail:drsibrahim@rocketmail.com
}

\begin{abstract}
Penelitian ini mengkaji falsafah hidup komunitas Adak Sampulonrua Buluttana dengan metode etnografi dalam pendekatan fenomenologi. Hasil yang ditemukan adalah: Pertama; Secara historis keberadaan AdakSampulonrua lahir sejak terbentuknya kampung Buluttana. Terbentuknya kampung Buluttana berawal dari keberadaan salah seorang keturunan Sombaya ri Gowa, yaitu Karaenta Data yang memisahkan diri dari kerajaan Gowa. Keberadaan Adak Sampulonrua pada tataran epistemologi mengalami perkembangan secara evolusi ada yang bersifat linear, ada yang bersifat progresif; namun pada sisi struktur tidak tersentuh dengan perubahan. Kedua; Wujud Falsafah Adak Sampulonrua masyarakat muslim Buluttana meliputi: Falsafah tau, falsafah pangnggadakkang, falsafah appasulapa serta falsafah siri'napacce. Ketiga; Nilai-nilai yang terkandung dalam keempat falsafah komunitas Adak Sampulonrua. Falsafah tersebut diaplikasikan dalam empat aspek, yaitu: patumbutau, patumbukatallassang, tumalla'langngi, dan tummoterangripammasena.
\end{abstract}

Keywords:

Adak Sampulonrua, Falsafah Hidup, Buluttana

\section{PENDAHULUAN}

Keberadaan umat manusia lazimnya ditinjau dari segi sosial dan berdasarkan daerah tempat tinggalnya, dicirikan dengan tingkah laku dan bentuk fisiknya, warna kulit dan bahasanya, suku dan bangsanya, pikiran dan bentuk kepercayaannya.Oleh karena itu, umat manusia memiliki agama dan budaya, tradisi dan adat istiadat yang berbeda-beda. Dari segi agama, seperti agama Majusi, Nasrani,Yahudi dan agama Islam. Dari aspek falsafah dan kepercayaan, seperti para filosof alam, filosof Yunani, dan filosof muslim.

Setiap agama dan budaya seperti yang disebutkan di atas, di dalamnya terdapat lagi beberapa paham atau aliran yang jumlahnya cukup banyak. Seperti aliran Jabariyah, aliran Qadariyah, aliran Muktazilah dan semacamnya dalam agama Islam, demikian pula halnya agama lain. ${ }^{1}$

${ }^{1}$ Lihat Abu al-Fath Muhammad bin Abd. al-Karīm al-Syahrastān̄̄, al-Milal wa alNihal, jilid I (Bairūt: Dār al-Kutub al-Ilmiah, t.th), h. 
Umat Islam di berbagai wilayah penjuru dunia, telah terbukti secara historis keberhasilan mereka dalam merealisasikan ajaran-ajaran Islam yang berkembang dengan mengadaptasi berbagai falsafah hidup, yang merupakan bentuk olahan kreativitas mereka dalam melakukan proses dialog dengan budaya lokal yang dihadapi. Pada akhirnya, Islam telah melahirkan berbagai corak peradaban yang sangat berpengaruh dan sangat luas jangkauannya. ${ }^{2}$ Oleh karena itu, kebesaran Islam sebagai agama samawi, yang berarti ajarannya bersumber dari Allah, senantiasa sejalan dengan budaya masyarakat, selama budaya tersebut tidak bertentangan dengan doktrin Islam; karena doktrin tersebut memasuki masyarakat dan mewujudkan diri dalam konteks sosial budaya (Islamicate) pada setiap wilayah atau kawasan.

Jadi sebagai agama, Islam mengatur manusia berdasarkan doktrin wahyu yang menjadi landasan akidah, syariah, dan akhlak, kemudian diaplikasikan dalam kehidupan sehari-hari, baik dalam beribadah maupun dalam menciptakan karyakarya budaya. Sehingga dalam bermuamalah yang lebih luas misalnya, umat Islam terikat dengan nilai-nilai akidah, syariah, dan akhlak dalam pengertian yang luas, agar dapat melahirkan falsafah hidup, kemudian akan terus mempengaruhi produk budaya yang dihasilkannya. ${ }^{3}$

Budaya adalah adat istiadat atau sesuatu yang telah menjadi tabiat dan watak masyarakat yang dapat dilihat dari kebiasaan sistem berpikirnya, gagasannya, dan tindakannya yang telah menjadi falsafah/pandangan hidup. ${ }^{4}$

Masyarakat muslim Bulutana memiliki budaya yang khas, yakni budaya lokal yang membedakannya dengan masyarakat lain di berbagai wilayah. Masyarakat muslim Bulutana misalnya, mereka memegang teguh budaya lokal berupa adat istiadat, tabiat asli, dan atau kebiasaan seperti assaukang, ajjaga, appalili, dan semacamnya. Berdasarkan observasi awal ditemukan beberapa situs tentang keberadaan Adak Sampulonrua Bulutana, yaitu balla lompoa dan balla Jambua, yang merupakan tempat masyarakat mengadakan ritual tertentu, serta beberapa acara ritual yang bertalian dengan acara sosial keagamaan dan atau sosial kemasyarakatan di Bulutana. Ditemukan pula pohon bersejarah yang dijadikan tempat menyajikan ritual assaukang dan atau appalili.

Buluttana seolah-olah menjadi kampung dengan 'hawa mistis'.Saat peneliti memasuki perkampungan tersebut, dijumpai pohon beringin rindang (kajuara) dipintu gerbang, berada tepat di jalan masuk kampung Bulutana. Dari keterangan penduduk setempat, diperoleh data bahwa rumah adat ini merupakan tempat

${ }^{2}$ Lihat Ajid Thohir, Perkembangan Peradaban di Kawasan Dunia Islam: Melacak Akar-akar Sejarah, Sosial, Politik, dan Budaya Umat Islam (Cet.I; Jakarta: PT. RajaGrafindo, Persada, 2004), h.2.

${ }^{3}$ Lihat Ajid Thohir, Perkembangan Peradaban di Kawasan Dunia Islam: Melacak Akar-akar Sejarah, Sosial, Politik, dan Budaya Umat Islam, h.7.

${ }^{4}$ Koentjaraningrat, Pengantar Ilmu Antropologi Budaya (Jakarta: Aksara Baru, 2003), h. 182. 
pertemuan pemangku Adak Sampulonrua, khususnya dalam membahas acara ritual appalili dan assaukang, serta ammoletinja (hajat).

Falsafah hidup sering juga disebut prinsip hidup, dalam pengertian prinsip yang dijadikan pedoman hidup oleh komunitas Adak Sampulonrua. Falsafah hidup tersusun dan merupakan hasil kerja simultan antara hati nurani, akal, budi, dan naluri sepanjang hidup manusia.Oleh karenanya, falsafah hidup terbentuk dan terus berkembang berdasarkan rangkaian pendidikan dan pengalaman hidup dari manusia dan atau komunitas.Falsafah hidup bersifat dinamis, dapat berubah secara alamiah seiring dengan perkembangan pendidikan dan pengalaman hidup manusianya.Hal ini sejalan dengan makna falsafah secara leksikal sebagaimana yang dikemukakan dalam Kamus Besar Bahasa Indonesia bahwa 'falsafah/ fal.sa.fah/ berarti anggapan, gagasan, dan sikap batin yang paling dasar yang dimiliki oleh orang atau masyarakat; pandangan hidup'.

Masyarakat muslim Bulutana Kecamatan Tinggimoncong Kabupaten Gowa memiliki adat istiadat yang khas serta falsafah hidup yang mengakar dalam kehidupan komunitas adat. Mereka sebagai muslim meyakini kebenaran ajaran Islam sebagai pedoman hidup beragama. Di samping itu, mereka memiliki kepercayaan tentang adanya kebiasaan yang dapat mendatangkan kemaslahatan bila diindahkan, tetapi bila diabaikan menjadi latar bencana.

Hal tersebut tercermin dalam tradisi yang telah mengakar pada masyarakat muslim, khususnya yang terhimpun dalam komunitas Adak Sampulonrua di Bulutana. Falsafah hidup yang menafasi komunitas adat Bulutana dalam berbagai aspek kehidupan sosial sarat dengan muatan teologis, baik yang terkandung dalam pesanpesan moral spiritual, maupun dalam upacara ritual yang telah menjadi tradisi.

\section{PEMBAHASAN}

\section{A. Sejarah dan Asal-Usul Adak Sampulonrua}

Di sebelah Barat pada ujung kampung Butta Toa Buluttana di atas tanah lapang diantarai oleh lapangan dan rumah warga yang terbuat dari rumah batu yang didesain secara modern berdiri dua buah rumah adat yang terbuat dari kayu dan bambu.Kontras dengan bangunan rumah warga di sekelilingnya karena terbuat dari batu bata dan semen.Kedua rumah adat (rumah panggung) yang material bangunannya berbahan kayu dan bambu itu sudah doyong sehingga harus ditopang oleh bambu pada sisi depan dan belakang. Meskipun sudah mengalami perbaikan di beberapa bagian.Dua buah rumah adat (rumah panggung) dengan tiang-tiang kayu besar dan berumur tua menyiratkan kesan etnik dan tradisional pada bentuknya.Bertahannya kedua rumah adat itu merupakan simbolisasi komunitas adat yang masih tetap setia menjaga dan melestarikan warisan dan sistem sosial-kultural dari nenek moyang secara turun-temurun

${ }^{5}$ Departemen Pendidikan Nasional, Kamus Besar Bahasa Indonesia, Edisi IV. (Cet. VIII. PT. Gramedia Putaka Utama, Jakarta: 2014), h. 387 
hingga saat ini. Pada segmen lain, praktik hidup keseharian masyarakat yang ramah, gotong royong, dan resiprositas yang kuat (saling berbalas budi) dalam menjalankan setiap acara/ritual berskala kampung ataupun keluarga menambahkan citra betapa luhurnya nilai-nilai adat tertanam dalam laku hidup masyarakat Adak Sampulonrua di Kelurahan Bulutana.

Sementara Balla Jambua dikenal juga sebagai balla karaeng yang artinya rumah atau kediaman untuk karaeng. Meskipun tidak ada data yang valid dan sumber yang otoritatif untuk menjelaskan usia rumah adat tersebut, tetapi beberapa tokoh masyarakat yang dituakan dan pemangku adat memperkirakan umur rumah adat itu sudah mencapai 300 tahun; bahkan menurut M. Saleh Silli, salah seorang dari keturunan pemangku adat dari silsilah gallarrang (bahkan isterinya yang bernama Dg. Bungalia mewarisi garis keturunan karaeng), mengemukakan bahwa kedua rumah adat ini didirikan sekitar tahun 1118, dengan demikian rumah adat tersebut sudah berusia sekitar 899 tahun. ${ }^{6}$ Namun, peneliti tidak menemukan sumber yang dapat memperkuat melalu triangulasi data.Kerumitan ini juga mendasari kompleksitas akan sejarah dan geneologi komunitas Adak Sampolorua di Buluttana.

\section{B. Wilayah Adat}

1. Rumah Adat dan Butta Toa Buluttana Sebagai Lokus Ritual Adat

“kemaemi bori' sanrapangna buluttana kaluku, kalongkong nilamung attimbo ngaseng",

Kelong (syair) tersebut di atas disampaikan dalam bentuk pertanyaan mengenai adakah kampung yang serupa dengan Buluttana; seluruh jenis bibit yang ditanam pasti akan tumbuh dan membuahkan hasil.Kampung yang selalu dirindukan. Setiap orang yang pergi kesana akan rindu untuk kembali ke kampung tersebut. Tempat dari komunitas adat Buluttana ini berada di lingkungan Butta Toa Buluttana.Namanya menyimbolkan kampung tersebut sebagai kampung yang sudah lama.Tempat ini lebih menyerupai puncak bukit datar yang berada di antara tebing-tebing.Tempat yang indah dengan pemandangan sungai mengalir di bawahnya menuju bendungan Bili-Bili terlihat berkelok dan tebing-tebing mengelilinginya. Kampung indah ini digambarkan dalam sebuah kelong, seperti nyanyian orang tua Buluttana di atas.

Balla Lompoaadalah rumah adat tempat tinggal gallarrang.Balla Lompoa lebih dikenal sebagai simbol dari kekuasaan atau pusat aktifitas gallarrang di Buluttana.Sedangkan Balla Jambu adalah tempat karaeng yang merupakan fokus aktivitas karaeng.Balla Lompoa serong ke Timur dan Balla Jambu menghadap ke Utara.Di antara keduanya sebuah alun-alun (lapangan) yang di ujung baratnya

${ }^{6}$ M. Saleh Silih (53 tahun) keturunan pemangku adat dari sisilah Gallarrang, Wawancara pada hari Selasa, 1 Agustus 2017 di Balla Jambua Butta Toa Buluttana. 
jelas berdiri mimbar yang digunakan untuk upacara ritual, khusunya acara ritual assaukang atau upacara appalili.Tampak jelas Islam telah menjadi sendi utama komunitas adat Buluttana.Apalagi jika melihat sebelah Utara gerbang jalan masuk menuju rumah adat berdiri sebuah masjid kecil bernama Nurul Jannah dibalik pohon rindang.

Menurut pengakuan Pak Saleh dan Ibu Japing (yang tinggal di Balla Lompoa),Balla Lompoa dan ballaJambua ini tidak diketahui sejak kapan didirikan dan siapa yang mendirikannya.Setahu mereka, kakek dan nenek mereka sendiri tidak tahu kapan dan siapa pendirinya.Kakek nenek saya saja tidak mengingat siapa yang mendirikannya.Dalam ingatan mereka bahwa sejak kecil rumah itu sudah ada berdiri, lahir dan besar disitu hingga saat ini, demikian pengakuan Pak saleh.Ia merupakan salah seorang tokoh adat anak seorang karaeng dan menantu dari seorang gallarrang.Dia mengaku dapat mewakili gallarrang atau karaeng jika orang tuanya berhalangan.

Balla Lompoa dan Balla Jambua adalah rumah yang menjadi pusat pelaksanaan ritual Adak Sampulonrua sekaligus menjadi simbol yang mengikat, dan menjadi pemersatu komunitas adat Buluttana. Rumah ini adalah rumah kayu yang ditopang oleh tiang-tiang kayu yang berukuran cukup besar, kurang lebih $30-40 \mathrm{~cm}$. Setiap sisinya tidak persis sama ukurannya tetapi hampir menyerupai persegi empat. Tiang ini tampaknya mengikuti lekuk asli batang kayu yang digunakan.

\section{Dari Butta Toa Buluttana, Lappara'Hingga Pemekaran Wilayah: Pola Migrasi Lokal dan Perluasan Wilayah Adat}

Dalam terminologi orang Buluttana, peristiwa migrasi lokal dimasa lampau disebut dalam tuturan sejarah mereka dengan istilah assulukang sisang. Proses migrasi lokal tersebut didorong oleh faktor demografi penduduk atau anggota komunitas Adak Sampulonrua yang semakin berkembang. Sementara, ada aturan adat yang melarang untuk membuat bangunan rumah diluar tujuh rumah yang telah ada di Butta Toa Buluttana pada masa itu.Akhirnya, sebagai solusi sebahagian kecil penduduk Butta Toa Buluttana memilih untuk pindah atau bermigrasi ke luar dari kawasan Butta Toa Buluttana untuk membuka pemukiman baru. Peristiwa assulukang sisang ini juga menjadi bagian dari proses perluasan wilayah adat oleh Adak Sampulonrua, hingga berlangsungnya proses pemekaran wilayah kelurahan Buluttana menjadi beberapa kelurahan.

Begitupun dengan lapparaatau Malino, bagi kebanyakan orang mengenal kotaMalino sebagai destinasi wisata, kawasan pegunungan, hutan pinus, dan air terjunnya yang menawan sekaligus sebagai ibu kota kecamatatan Tinggimoncong. Saat ini kota Malino cukup menarik perhatian dari berbagai sektor, khususnya sektor ekowisata. Olehnya itu, pemeritah daerah kabupaten Gowa memacu pembangunannya untuk dijadikan salah satu lokasi wisata 
yangakan dikenal oleh dunia. Salah satu buktinya, kebun teh dibawah pengelolaan PT Nitto diakuisisi oleh perusahaan asing lalu disulap menjadi suatu kawasan perkebunan teh sekaligus tempat wisata untuk meniknati panorama pegunungan berkabut; dari atas bukit sembari menghirup udara segar dan aroma

Asal mula kata "Buluttana' berasal dari bahasa Makassar asli yakni “ bulu' yang berarti bukit dan 'tana' yang berarti tanah. Menurut pesan leluhur atau pasang turiolo bahwa dulu kala di kerajaan Gowa terdapat raja yang beroposisi yang dikenal dengan nama 'Karaengta Data' dalam perjalanannya menemukan suatu kampung yang terletak diatas bukit yang sangat strategis dan dapat dijadikan benteng pertahanan dimana kampung ini bernama Buluttana yang artinya pertahanan di atas bukit. Kampung ini memang bila dilihat letak geografisnya tepat sekali dijadikan pertahanan, dimana hanya ada satu jalur saja untuk keluar masuk.

Nama Kelurahan Buluttana secara etimologi kata Buluttana adalah bahasa Makassar yang berakar dari kata buluk dan tana. Dalam kamus bahasa Makassar

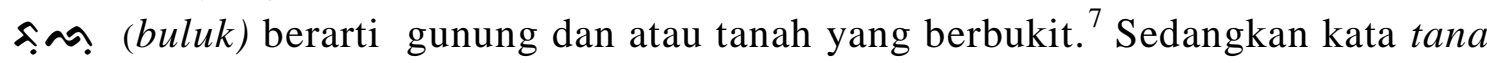
dalam kamus bahasa Makassar Indonesia berarti sawah. ${ }^{8}$ Dengan demikian, kata Buluttana merupakan kata jadian yang berakar dari katabuluk dan tana. Selanjutnya, berdasarkan data wawancara dengan H. Mustari Ago, salah seorang pemuka adat menjelaskan bahwa "yang dimaksud dengan "Buluttana" adalah "Butta Toa Buluttana” yaitu suatu kampung tertua yangterletak dipinggir sungai Jeneberangyaitu bukit yang terletak pada dataran rendah. Kampung tersebut merupakan cikal bakal lahirnya Kelurahan Buluttana. ${ }^{9}$

\section{Wujud Adat: Landasan Kultural dan Basis Nilai Komunitas Adak Sampulonrua}

Pandangan hidup orang Buluttana atau anggota komunitas Adak Sampulonrua, berakar pada empat pokok ajaran yang menjadi sumber nilai sebagai pedoman dalam menata keseimbangan dalam relasi-relasi sosio kultural dalam masyarakat, menjaga kelestarian alam, dan sebagai upaya melestarikan tradisi dan eksistensi adat.Menariknya, penulis melihat bahwa sumber nilai ajaran ini tidak diterapkan secara kaku melainkan dinamis terhadap perkembangan zaman.Artinya, nilai-nilai yang terkandung dalam falsafah Adak Sampulonrua selalu mengakomodir dan juga memfilter nilai-nilai baru tergantung sejauh mana nilai baru tersebut bermanfaat bagi kepentingan masyarakat, tetapi sekaligus menolak yang berpotensi merusak keseimbangan sosial dalam masyarakat.Singkatnya, budaya tersebut selalu melakukan 'negoisasi' dengan hal.19.

${ }^{7}$ Pemerintah Kelurahan Buluttana, Profil Kelurhana Buluttana, Legenda dan Sejarah,

${ }^{8}$ Aburaerah Arief, Kamus Makassar Indonesia, h. 406.

${ }^{9}$ H. Mustari Ago (75 tahun ) Pemuka Adat Dua Belas Buluttana sekaligus sebagai mantan Lurah Buluttana Wawancara Lombasang Kelurahan Buluttana, 28 Agustus 2013. 
gerak perubahan dan dinamika zaman. Empat pokok landasan nilai adat bagi komunitas Adak Sampulonrua adalah sebagai berikut:

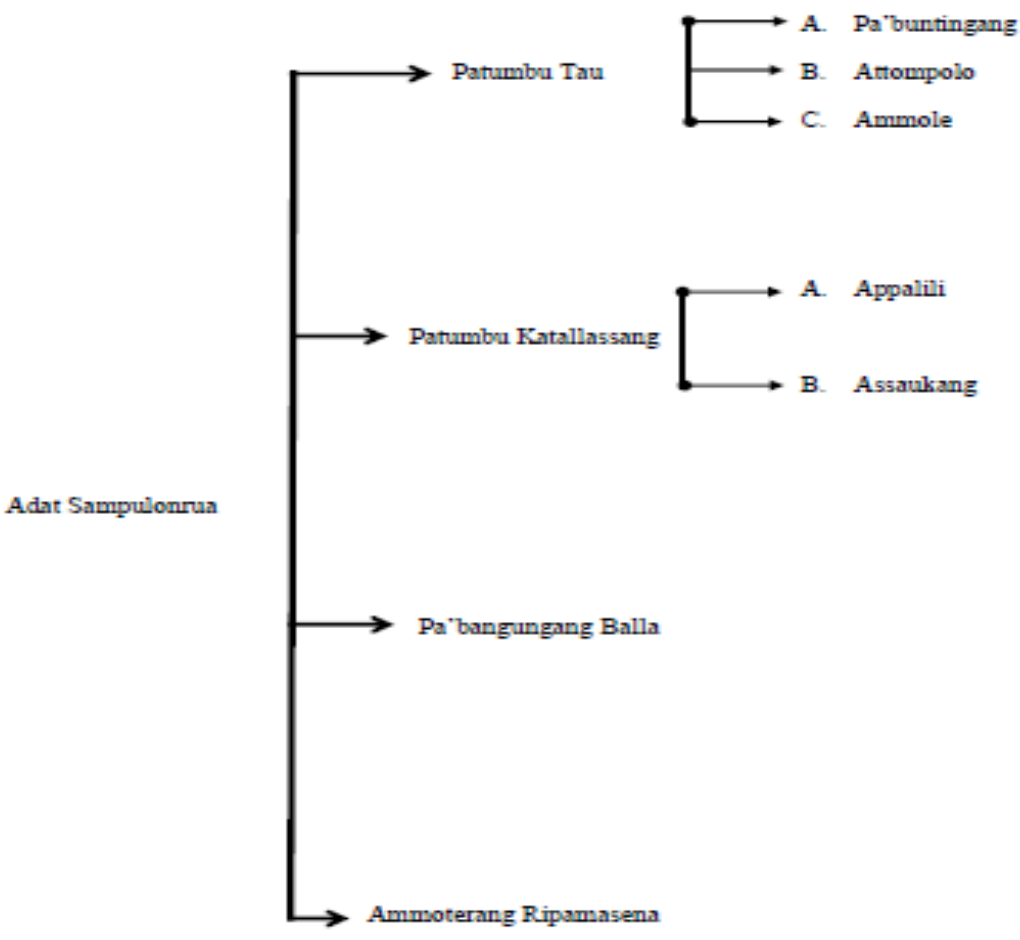

\section{PatumbuTau}

Patumbu Tau merupakan salah satu nilai dasar (ajaran utama) AdakSampulonrua yang dapat dimaknai sebagai upaya adat untuk menjaga, melestarikan dan mengembangkan sumber daya manusia demi keberlangsungan generasi anggota komunitas Adak Sampulonrua sejak kecil hingga membentuk keluarga baru.Penggolongan beberapa praktik adat kedalam kategori PatumbuTau dibawah ini berdasarkan olahan dari berbagai sumber dan analisis penulis. Berikut praktik atau wujud adat dalam falsafah Patumbu tau:

\section{a. Attompolo}

Budaya Attompolo, adalah prosesi budaya akikah bagi keluarga terhormat dalam memberikan nama pada anak dan proses pasca-aqiqah. Budaya ini telah berlangsung cukup lama, yang ramainya dapat seperti pesta pernikahan. ${ }^{10}$ Acara aqiqah, merupakan budaya ritual bagi bayi yang baru lahir.Pada acara ini, sebelumnya diadakan penyembelihan kambing bagi bayi yang baru lahir, satu ekor kambing untuk bayi perempuan dan dua ekor kambing untuk bayi laki-laki.

\section{b. Pa'buntingang}

${ }^{10}$ M. Asdar Nanjeng, Tokoh Masyarakat-Mantan Kepala Desa.Wawancara oleh penulis di Silanggaya pada tanggal 21 Agustus 2013. 
Pabbuntinganmerupakan budaya dalam sistem perkawinan bagi masyarakat muslim Buluttana. Pabbuntingan dianggap sebagai suatu yang sakral dan abadi sehingga harus dilaksanakan melalui upacara-upacara tertentu dengan berbagai adat istiadatnya. Bagi masyarakat muslim Buluttana, menikahkan anak secepat mungkin merupakan budaya yang baik, mereka menyindir orang yang

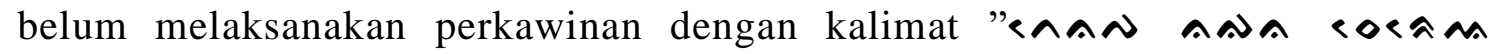

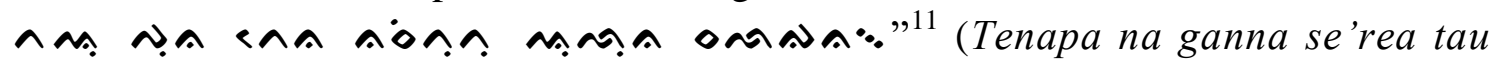
punna tenapa na situtu ulunna salangganna); maksudnya seseorang belum menjadi manusia sempurna apabila kepalanya belum menyatu antara kepala dengan bahunya. Makna dari ungkapan dalam bahasa mereka disebut "tau" bila ia sudah menikah atau sudah berkeluarga.

\section{c. Ammole}

Ammolemerupakan salah satu ritual yang dilaksanakan oleh pemangku adat ketika seseorang tamu datang untuk menunaikan janjinya (nazar) yang pernah dihajatkan.Misalnya, seseorang itu pernah hidupnya susah lantas lambat laun kehidupannya berubah menjadi kaya raya; ataukah orang itu pernah sakit parah kemudian dia mendapatkan kesembuhan. Orang-orang yang pernah bernazar inilah yang kemudian datang ke pemangku adat agar diselenggarakan acara adat tersebut.Biasanya mereka menyembelih binatang (berkorban) berupa sapi, kambing, ayam, ataukah paling sederhana membawa pisang sebagai jamuannya.Umumnya, mereka yang datang Ammole memiliki kaitan geneologis dengan Buluttana.Nenek moyang mereka adalah orang Buluttana yang pergi meninggalkan kampungnya dalam waktu yang lama. Ritual ini memiliki tahapan pelaksanaan sebagai berikut: pemangku adat akan menggelar pertemuan untuk menentukan waktu penyelenggaraan ritual tersebut.

\section{Patumbu Katallassang}

Nilai filosofis yang terkandung dalam AdakSampulonrua tentang patumbu katallassang terletak pada upaya masyarakat adat atau komunitas adat mengelola dan melestarikan sumber-sumber daya alam atau potensi alam untuk meningkatkan kesejahteraan bersama seluruh anggota komunitas adat.Di samping itu, patumbu katallassang juga berperan sebagai landasan utama dalam menata dan mengatur sumber layanan alam yang melimpah untuk dikelola dan dimanfaatkan oleh seluruh masyarakat adat di Buluttana. Di bawah ini akan diuraikan beberapa wujud dari segmen patumbu katallassang yang sampai saat ini masih terus dilestarikan dalam kehidupan sehari-hari oleh komunitas AdakSampulonrua tersebut.

a. Appalili

Ritual tahunan yang dilaksanakan oleh komunitas adat masyarakat muslim Buluttana sebagai tanda memulai pekerjaan sawah untuk menanam padi. Appalili

${ }^{11}$ H. Talla, Mantan Kesra Kelurahan Buluttanna, Wawancara oleh penulis di Lombassang pada tanggal 20 Agustus 2016. 
dalam falsafah AdakSampulonrua merupakan salah satu bentuk ritual dalam patumbu katallassang. Appalili bermakna doa dan upaya adat untuk merawat, memelihara dan meningkatkan hasil sawah dalam rangka mensejahterakan masyarakat. Appalili merupakan salah satu rangkaian dari proses pertanian dalam penentuan waktu tanam, penaburan benih, pengwilayahan benih, hingga waktu panen. Sebelum ritual awal mula di sawah ini dilakukan, para pemangku adat melakukan musyawarah adat yang bertujuan untuk menetapkan waktu appalili, menetukan jenis benih yang akan ditanam, hari untuk membajak sawah, menanam benih dan waktu panen. Setelah pemangku adat menyepakati jadwal tanam padi; selanjutnya, pemangku adat mensosialisasikan kepada masyarakat luas dan pemerintah setempat.

\section{b. Assaukang}

Assaukang adalah salah satu acara adat Buluttana yang namanya diambil dari istilah makassar yaitu "assau-sau” yang berarti melepaskan rasa letih setelah beberapa bulan melakukan pekerjaan di sawah seperti membajak sawah, menanam hingga memanen.Dari hasil panen itulah kemudian dikumpulkan oleh masyarakat Buluttana di rumah adat lalu kemudian membuat sebuah acara sebagai tanda syukur atas hasil panen yang telah didapatkan. Acara ini dilakukan secara besar-besaran dan dilakukan rutin sekali dalam setahun, dimana berkumpul para pemangku adat, tokoh masyarakat, aparat pemerintahan dan seluruh masyarakat Buluttana. Secara khusus, hasil panen tersebut didapatkan dari sawah adat yang dikumpul sebagian pada lantai dua rumah adat, kemudian secara umum masyarakat yang mengikuti acara tersebut juga membawa beberapa hasil panen mereka, dan sebagai tanda syukur mereka membuat acara lalu makan bersama sebagai suatu wujud kebahagiaan dalam hasil bumi yang didapatkan.

\section{Pa'bangungang Balla}

Salah satu bentuk dari pelestarian adat di Buluttana terlihat dari kolektifisme warganya, baik yang bersifat publik maupun yang individual.Seperti pembangunan jalan, bersih-bersih lingkungan hingga gotong royong ketika ada seorang warga yang ingin membangun rumah (pa'baungang balla). Namun kerja kolektif warga ini bukan sekedar kerja fisik saja tetapi juga saling tolong menolong dalam urusan pemenuhan kebutuhan logistik suatu penyelenggaraan pesta.

\section{Tummoterang riPamasena}

Tummoterangri Pammasena artinya orang yang berpulang kerahmatullah, Prosesi penyelenggaraan tummoterangripammasena bagi masyarakat Buluttana dapat dikaji dari dua aspek, baik dari aspek budaya maupun dari aspek agama.

\section{Identitas Adat dan Spiritualitas Islam di Masyarakat Muslim Buluttana}

Komunitas Adak Sampulonrua Buluttana memberikan perspektif baru tentang beragamnya bentuk-bentuk akomodasi adat dan ajaran Islam di Sulawesi 
Selatan.Hal-hal yang umum misalnya, dapat ditemukan dalam sejumlah penelitian tentang Islamisasi di Sulawesi Selatan menunjukkan bahwa amat sulit memisahkan antara nilai-nilai adat dengan nilai-nilai ajaran Islam, sebab keduanya telah menyatu dan saling menguatkan.Ketika Islam pertamakali masuk ke Sulawesi Selatan dan menjadi agama kerajaan; sehingga menjadi agama wajib dianut bagi seluruh masyarakat.Bahkantelah ditemukan fakta bahwa adat dan syariat telah terintegrasi dalam praktik sosial, struktur politik, ritualitas seharihari.Tidak lama setelah Islam dianut menjadi agama kerajaan.

\section{Falsafah Hidup dalam AdakSampulonrua}

Kata falsafah (dalam bahasa Arab) atau filsafat (dalam bahasa Indonesia) merupakan kata serapan dari bahasa Arab yang juga merupakan kata serapan dari bahasa Yunani, yaitu dari kata philosophia.Kata philoshopia dalam bahasa Yunani merupakan kata majemuk yang berakar dari kata philo dan shopia.Philo berarti cinta, yang bermakna usaha yang sungguh-sungguh untuk memahami sesuatu; sedangkan kata shopia berarti bijaksana.Bijaksana dalam hal ini, bermakna pengetahuan yang mendalam.Pengetahuan yang mendalam itulah esensi pengetahuan terhadap sesuatu. ${ }^{12}$ Dengan demikian, secara leksikal kata filsafat berarti usaha yang sungguh-sungguh untuk menemukan hakikat sesuatu (kebenaran).

Seyyed Hosein Nasr dalam Ensiklopedi Tematis Filsafat Islam memaparkan bahwa 'Berdasarkan Al-Qur'an dan hadis yang di dalamnya digunakan istilah hikmah.' Para cendikiawan muslim memberi makna hikmah sebagai falsafah;suatu istilah yang diserap ke dalam bahasa Arab melalui penerjemahan teks Yunani, dalambahasa Inggris disebut sebagai philoshophy. Seyyed Hosein Nasr memandang perlu dilacak dalam berbagai konteks peradaban Islam yang mengembangkan cabang-cabang tertentu filsafat, karena setiap mazhab pemikiran mendefinisikan kata hikmah atau falsafahberdasarkan perspektifnya sendiri-sendiri sehigga persoalan ini menarik dikaji lebih lanjut. ${ }^{13}$

Pandangan tentang filsafat tersebut serta makna yang terkandung di dalamnya menjadi inspirasi bagi peneliti dalam mendeskripsikan falsafah hidup komunitas Adak Sampulonruamasyarkat muslimBuluttana. Komunitas adat Masyarakat muslim Buluttana memiliki falsafah hidup yang dijadikan tatanan kehidupan sosial. Falsafat tersebut meliputi:
a. NMON $\wedge$ M. (Falasafa tau),

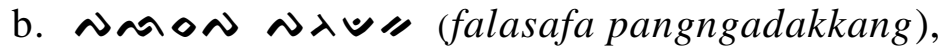
c. NMON MN OMN (falasafa appa sulapa) sulapak), dan

\footnotetext{
${ }^{12}$ Disadur dari Ahmad Tafsir.Filsafat Umum; Akal dan Hati Sejak Thales Sampai James, (cet. I. Bandung: PT. Remaja Rosdakarya, 1990), h. 8.

${ }^{13}$ Lihat dari Seyyed Hossein Nasr dan Oliver Leman, Ensiklopedi Tematis Filsafat Islam, (Cet. I; Bandung: Mizan, 2003), h. 29.
} 


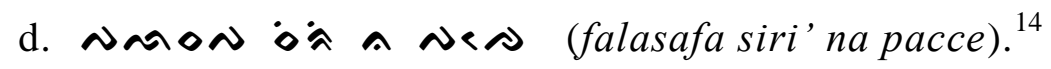

\section{Komunitas Muslim di Buluttana: Kategorisasi Masyarakat AdakSampulonrua dan Hubungannya dengan Islam}

Terdapat berbagai macam bentuk akomodasi dan akulturasi antara agama dan budaya atau tradisi dalam suatu masyarakat.Penelitian ini juga menemukan bahwa akulturasi dan integrasi tersebut terjadi di komunitas AdakSampulonrua di Buluttana.Bentuk akulturasi tersebut telah berlangsung sangat lama, sehingga nilai-nilainya juga terinternalisasi dalam setiap praktik hidup sehari-hari.Untuk lebih memahami bentuk-bentuk akulturasi dan akomodasi Islam dalam komunitas AdakSampulonrua di Buluttana, penelitian ini hendak menampilkan deskripsideskripsi sebagaimana fenomena yang diamati.

Akan tetapi, peran sanro sudah banyak bergeser atau berubah seiring dengan perubahan zaman.Dulunya sanropunya peran yang lebih luas tidak hanya ketika perayaan atau ritual adat dilaksanakan, tetapi juga terkait dengan kesehatan dan pemberkatan.

Dulu sanro itu sama dengan dukun, tabib karena ketika ada warga yang sakit, mereka akan datang ke sanro untuk minta diobati. Begitu juga kalau ada acara-acara keluarga seperti sunatan, khitanan atau syukuran kecil-kecilan, lazimnya para warga akan datang ke sanro untuk didoakan atau diberkati. Seiring perkembangan zaman, peran-peran sanromulai digantikan oleh mantri kampung atau dokter dan juga imam desa atau ustadz.Menariknya, peran sanro masih dibutuhkan oleh anggota komunitas meskipun sudah mulai terbatas.

Kondisi demikian yang menjadikan sanrodan beberapa pemangku adat lainnya tetap memakai adat sebagai suatu nilai ajaran, perilaku, dan pertimbangan adat dalam urusan antar-anggota komunitas lainnya.Dengan demikian, Islam tetap menjadi agama dan keyakinan namun tidak diamalkan secara taat, singkretis, percaya pada hal-hal mistis dan cenderung mengakulturasikan antara syariat dengan adat istiadat.

Pak Lingkungan sering menyampaikan secara terbuka kepada kami bahwa "Nda adami adat itu. Tinggal orang-orang tua yang tau.Saya ini nda kutau semuami". 15 Penyampaiannya disampaikan dengan nada yang lebih pesimistik atas realitas dan masa depan identitas adat di masyarakatnya yang makin tergerus oleh praktik-praktik dan pemaknaan modern. Dia bahkan pernah menyampaikan “sisa satu generasi lagi kayaknya adat sudah tidak lagi kuat”. Meski demikian, betapapun dia tidak lagi merasa terikat dengan adat dan merasa tidak lagi memahami dan karena itu jauh dari adat, suatu ketika dia juga pernah mengantar ibunya membawa hajat ke ballalompoa untuk ammole. Dia membawa pisang raja yang dibelinya di pasar, membawa perlengkapan-perlengkapan lain dan

\footnotetext{
${ }^{14}$ Dg. Ngoting ,TauToanaAdaka. Wawancara di Tanetea tanggal 10 Agustus 2015.

${ }^{15}$ Dialog dengan Muh. Saleh Dg. Nompo, kepala lingkungan Butta Toa Buluttana. Pada tanggal 15 Maret 2017.
} 
membawa ibunya bertemu dewan adat yang kemudian menyelenggarakan upacara atas permintaan ibunya.Di sini terlihat betul, generasi lama yang diwakili ibunya, memahami adat lebih utama daripada syariah dan menjalankan sejumlah ritual adat.

Kategorisasi Kedua, adalah masyarakat Adak Sampulonrua Buluttana yang identitasnya berkaitan dengan Islam lebih dalam dan karena itu lebih mengedepankan praktik Islam dan pemahaman Islamnya dibandingkan dengan praktik adat dan ritualnya. Terdapat kesan bahkan, orang-orang yang lebih mengedepankan pemahaman keislamannya, atau sering disebut 'Islam Parewa Syara', menganggap bahwa praktik adat sudah makin tidak relevan dan pada posisi-posisi tertentu melihat adat lebih inferior dibanding modernitas dan pemahaman keislamannya.

Berdasar pada ilustrasi di atas, mengikuti pandangan Clifford Geertz dalam studinya tentang trikotomi agama Jawa. Geertz kemudian membagi kategori masyarakat Jawa menjadi tiga kelompok berdasarkan religiusitas masyarakat Jawa, yakni: Priyayi, Abangan dan Santri. ${ }^{16}$ Senada dengan pandangan Geertz di atas, Nurman Said dalam studinya melihat masyarakat muslim Makassar dalam konteks pola-pola integrasi sosial antara muslim pagama dan muslim sossorang di Sulawesi Selatan. Said membagi antara kategori masyarakat muslim yang taat menjalankan syariat Islam dengan istilah muslim pagama, sementara masyarakat muslim Makassar yang kurang taat disebut dengan istilah muslim sossorang atau yang lebih lazim dikenal dengan Islam KTP (merujuk pada identitas Agama dalam kartu tanda penduduk). ${ }^{17}$

Terdapat bentuk respon antara adat dan Islam lainnya, yang kecenderungan mereka tidak lagi menginternalisasi nilai-nilai adat secara ketat, bahkan mengarah pada ketidakpercayaan terhadap adat yang dianggap mendekati praktik syirik dan musyrik dan bertentangan dengan ajaran Islam. Tipologi untuk mengidentifikasi kategori tersebut bukan termasuk pemangku adat, berpendidikan, menjalankan agama secara taat, tetapi melihat adat secara positif atau sebagai norma sosial. Kategori ini disebut Islam ParewaSyarak atau mengamalkan syariat Islam sesuai ajarannya.

Dalam komunitas AdakSampulonruajuga mengalami pertentangan terutama terkait dengan beberapa ritual adat yang dituding mendekati syirik, bahkan yang menentang berasal dari anggota komunitas dan keturunan pemangku adat, seperti misalnya; H. Abdul Gani (Ketua karang taruna Buluttana) dan H. Abd. Hamid Sarro (pimpinan pesantren) yang seorang tokoh masyarakat dan merupakan keturunan dalam silsilah Bakulompo yang lebih melihat adat sebagai

\footnotetext{
${ }^{16}$ Clifford Geertz, AgamaJawa; Abangan, SantridanPriyayidalamKebudayaanJawa, (Jakarta: Komunitas Bambu, 2013), h, 15.

${ }^{17}$ Nurman Said, Masyarakat Muslim Makassar: Studi Pola-Pola Integrasi Sosial Antara Muslim Pagama dengan Muslim Sossorang, ( Cet. I ; Jakarta: Badan Litbang dan Diklat Departemen Agama RI, 2009), h, 145.
} 
norma sosial untuk mengatur masyarakat dan membantu pemerintah untuk mengayomi masyarakat Bulutana. Diluar fungsi itu, ia menolak singkretisme adat bahkan berupaya menafsirkan tradisi yang berlaku dengan pendekatan yang lebih Islami.

\section{Komunitas Adak Sampulonrua dalam Perubahan}

Tidak dapat dipungkiri bahwa dalam dunia sosial, terjadi proses perubahan. Dalam teori perubahan sosial melihat masyarakat senantiasa berubah pada semua tingkat kompleksitas internalnya. Di tingkat makro terjadi perubahan ekonomi, politik, dan kultur. Di tingkat mezo terjadi perubahan kelompok, komunitas, dan organisasi. Sedangkan pada level mikro yang terjadi perubahan interaksi dan perilaku individual. ${ }^{18}$

Komunitas Adak Sampulonrua Sebagai sebuah komunitas yang tidak tertutup oleh pengaruh perkembangan dunia sosial yang lebih luas, mengalami dinamika perkembangan dan juga perubahan.Dalam praktik adat misalnya, pelaksanaan ritual appaliliawalnyamenggunakan kerbau, sebagai hewan yang digunakan dalam upacara tersebut.Akan tetapi, sejak beberapa tahun terakhir ketika kerbau menjadi semakin langka ditemukan karena ternak masyarakat diganti menjadi sapi impor yang lebih mudah perawatan dan lebih cepat perkembangannya, sehingga komunitas adat menggunakan sapi sebagai perangkat dalam upacara adat untuk menggantikan kerbau.

Hal ini dilakukan, sebab selain kerbau semakin sulit ditemukan, sapi juga lebih sulit untuk dilatih membajak, maka jalan yang paling mudah untuk itu adalah menggunakan traktor.Hal ini diakui secara tidak langsung oleh seorang kepala lingkungan yang juga merupakan anggota dari komunitas adat yang tinggal tidak jauh dari kawasan adat Butta Toa Buluttana. ${ }^{19}$

Hal serupa juga terjadi dalam praktik-praktik perkawinan adat yang menjadi semakin ringkas, praktis dan efisien.Berbeda dengan ketika komunitas adat melaksanakannya sesuai dengan aturan-aturan adat sepenuhnya.Saat ini terdapat banyak perkawinan dalam wilayah adat, yang tidak lagi menggunakan urutan dan perangkat yang lengkap sesuai tuntunan adat tertua jika perangkat adat berhalangan untuk hadir.

Dalam dua kasus di atas, diperlihatkan kalau adat dan ritualnya bukanlah sesuatu yang terisolasi secara sosial dari pengaruh lingkungan dan dunia sosial yang berubah di sekitarnya.Ketika kerbau menjadi binatang langka sebab masyarakat mengintroduksi sapi sebagai hewan ternak, perangkat bertani berganti

\footnotetext{
${ }^{18}$ Piotr Sztompka, Sosiologi Perubahan Sosial, (Ed.1. Cet.3; Jakarta: Prenada, 2007), h.65.

${ }^{19}$ Dialog dengan Muh. Saleh dg. Nompo, kepala lingkungan Butta Toa Buluttana. Pada tanggal 15 Maret 2017.
} 
menjadi sapi. Ketika kerbau dan sapi tidak lagi efektif maka traktor dapat menggantikan proses pembajakan sawah.

Bahkan untuk upacara siklus hidup penting seperti perkawinan juga tidak dapat mempertahankan diri sepenuhnya untuk tetap menggunakan perangkatperangkat adat yang rumit dan panjang untuk digantikan oleh praktik perkawinan yang minimalis dan lebih efisien.Selama syarat-syarat minimal sesuai syariat telah terpenuhi, maka perkawinan dianggap dapat dilakukan dengan mengadaptasikan nilai-nilai falsafah adat dalam tata cara perkawinan yang Islami dan modern.

Pada konteks di atas, tradisi dapat dilihat sebagai warisan sosial yang dalam konsep tradisi warisan sosial jika terjadi ditingkat makro maka semua diwarisi masyarakat dari fase-fase proses historis terdahulu merupakan 'warisan historis. Lalu, apa saja yang diwarisi komunitas atau kelompok dari fase kehidupan terdahulu akan menjadi 'warisan kelompok'. Dengan demikian, tradisi appalili, pa'buntingan, assaukang, serta yang lainnya, termasuk konsep tradisi sebagai warisan kelompok terdahulu. Akan tetapi, tradisi, begitu terbentuk akan mengalami berbagai perubahan. ${ }^{20}$

\section{4. "Keterlepasan dan Keterikatan": Keanggotaan Adak Sampulonrua}

Terdapat beberapa peristiwa yang diingat oleh masyarakat Adak Sampulonrua mengenai seorang perangkat adat diusir dari lingkungan adat karena mendatangi rumah anaknya yang melakukan praktik kawin lari.Dalam istilah kebudayaan Makassar ini disebut annyala.Tidak ada perangkat adat maupun anggota adat yang dapat dianggap sebagai anggota adat jika melanggar adat yang prinsipil.Salahsatunya adalah kawin lari.Kawin lari dapat menyebabkan seseorang menjadi terlepas secara kekerabatan dan secara adat dari komunitas AdakSampulonrua.Jika kerabat atau keluarganya ketahuan datang mengunjungi atau menjumpai keluarganya yang melanggar adat tersebut, dia juga dianggap terlepas dari ikatan adat.Hal ini menunjukkan jika menjadi anggota dan perangkat Adak Sampulonrua juga merupakan sesuatu yang tidak sederhana meski juga tidak terlepas dari perubahan-perubahan praktik dan pemaknaan.

Keterlepasan dari keanggotaan adat di atas telah beberapa kali terjadi di komunitas AdakSampulonrua.Ini adalah penjelasan, bagi peneliti, mengenai bagaimana seseorang terlepas dari keanggotaan adat.Sedangkan sebaliknya, menurut sejumlah sumber, sesorang yang dianggap sebagai anggota adat dapat sangat longgar pemaknaannya.

Pertama, berdasarkan wilayah geografis wilayah kekuasaan adat.Ada yang menganggap bahwa orang-orang yang tinggal dibawah wilayah adat adalah anggota komunitas adat.Baik penduduk asli maupun yang datang oleh ikatan perkawinan di wilayah adat tersebut.

\footnotetext{
${ }^{20}$ Lih.Piotr Sztompka, Sosiologi Perubahan Sosial, h. 69.
} 
Kedua, anggota adat tergolongpula mereka yang tinggal atau bermukim di luar wilayah adat tetapi diketahui oleh masyarakat adat sebagai anggota atau perangkat Adak Sampulonrua. Untuk itu perlu dijelaskan kenapa karaeng, atau ketua adat dan banyak perangkat adat juga tidak bermukim di wilayah adat tetapi di kota Sungguminasa.

Ketiga, anggota adat dapat berupa komunitas atau individu yang mengaku menjadi bagian dari Adak Sampulonrua yang diketahui dari hubungan kekerabatan dan darah yang telah lama tetapi diingat kembali oleh mereka. Banyak kasus upacara ammole dilakukan oleh orang di luar wilayah adat, bahkan sering datang dari wilayah yang cukup jauh seperti kabupaten Bone, Kabupaten Bulukumba, kota Makassar, Balikpapan, dan lain-lain karena merasa ada kaitan dengan komunitas Adak Sampulonrua. Oleh karena itu, ketika hajat mereka terpenuhi, maka ia melakukan acara syukuran di Balla Lompoa di kawasan adat Butta Toa Buluttana.Sebagai contoh dapat dilihat jumlah keluarga yang datang untuk melakukan acara ammole di Butta Toa Buluttana yang merupakan orangorang yang berasal dari luar Buluttana.

\section{DAFTAR PUSTAKA}

Al-Qur'ān al-Karīm

Abdullah, M. Amin, Islamic studies di Perguruan Tinggi pendekatan IntegratifInterkonektif.Yogyakarta: Pustaka Pelajar, 2010.

Abidin Farid, Andi Zainal. "Siri'-Pesse dan Were Pandangan Hidup Orang Bugis” dalam Siri dan Pesse; Harga Diri Manusia Bugis, Makassar, Mandar, Toraja. Makassar: Pustaka Refleksi, 2005.

Adian, Donny Gahral.Pengantar Fenomenologi. Cet. 1; Depok: Penerbit Koekoesan, 2010.

Arikunto, Suharsimi. Prosedur Penelitian; Suatu Pendekatan Praktek. Cet. IX; Jakarta: Renika cipta, 1993.

Arief, Aburaerah. Kamus Makassar - Indonesia,Cet. I; Ujung Pandang: Yayasan Yapik DDI, 1995.

Andaya, Leonard Y. Warisan Arung Palaka. Makassar: Penerbit Inninawa, 2004.

Anderson, Benedict R. O'G. Language and Power: Exploring Political Cultures in Indonesia. Ithaca: Cornell Up, 1990.

al-Hafid, Radhi. Cerita Prosa Rakyat, Studi tentang Peranannya dalam Agama dan Perubahan Sosial pada Masyarakat Bugis di Kabupaten Sidenreng Rappang dalam Andi Rasdiyanah. Bugis-Makassar dalam Peta Islamisasi Indonesia, ed. Ujungpandang: IAIN Alauddin, 1982.

Ali, Muhammad. The Religion of Islam diterjemahkan oleh R. Kaelan dan H.M. Bahrun dengan judul Islamologi.Jakarta: Ikhtiar Baru: 1997. 
Alisjahbana, S. Takdir. Antropologi Baru: Nilai-nilai sebagai Tenaga Integrasi dalam Pribadi, masyarakat dan Kebudayaan. Jakarta: Universitas Nasional dan P.T. Dian Rakyat, 1986.

Ash-Shiddiqy, Muhammad Hasbi.Pedoman Zikir dan Doa. Cet. III; Semarang: Pustaka Rizki Putra, 1999.

Asy'ari, Musa. Agama dan Kebudayaan dan Pembangunan Menyonsong Era Industrialiasasi. Yogyakarta: Amara Buku, 1988.

Awliya, Fakhira, dkk. Sultan Mahmud Abdullah The Grent Pattingalloang Cendikiawan Visioner Masa Prakolonial 1600 - 1654. Cet. I; Jakarta: The Gemma Nine National Institute For Empowerment, 2015.

Azra, Azyumardi. Jaringan Ulama Timur Tengah dan Kepulauan Nusantara Abad XVII dan XVIII. Bandung: Mizan, 1995.

Bagus, Lorens. Kamus Filsafat. Jakarta: PT. Gramedia Pustaka Utama. 2005.

Buijs, Kees. Kuasa Berkat, Dari Belantara dan Langit; Struktur dan Transformasi Agama Orang Toraja di Mamasa Sulawesi Barat.Makassar: Inninawa, 2009.

Berger, Peter, L dan Thomas Luckman. Tafsir Sosiologi Pengetahuan. Cetakan Pertama; Jakarta: LP3ES, 1990.

Bourdieu, Pierre. Arena Produksi Kultural; Sebuah Kajian Sosiologi Budaya.Bantul: Kreasi Wacana, 1993.

Braginsky, V. I. Tasawuf Dan Sastera Melayu, Kajian dan Teks-Teks. Jakarta: Seri Publikasi Bersama antara Pusat Pembinaan dan Pengembangan Bahasa dengan Universitas Leiden, 1993.

Daeng, Hans, J. Manusia. Kebudayaan dan Lingkungan; Tinjauan Antropologi. Yogyakarta: Pustaka Pelajar, 2008.

Denzin, Norman K. dan Lincoln, Yvonna S., (Eds).Handbook of Qualitative Research( Yogyakarta: Pustaka pelajar, 2009).

D’Andrea, Claudia. Kopi, Adat dan Modal ; Teritorialisasi dan Identitas Adat di Taman Nasional Lore Lindu Sulawesi Tengah. Yogyakarta: Sayogyo Institute, YTM dan Tanah Air Beta. 2013.

Dewi, Saras. Ekofenomenologi, Mengurai Disekuilibrium Relasi Manusia Dengan Alam. Tanggerang Selatan: Marjin Kiri, 2015.

Dewantara,Ki. Hadjar.Asas-asas dan dasar-dasar Taman Siswa. Yogyakarta: Majelis Luhur Taman Siswa, 1964.

Departemen Agama RI. Al-Qur'an dan Terjemahnya. Jakarta: Proyek pengadaan Kitab Suci al-Qur'an, 2002.

Departemen Pendidikan Nasional.Kamus Besar Bahasa Indonesia. Jakarta: Balai Pustaka, 2002.

Departemen Pendidikan Nasional, Kamus Besar Bahasa Indonesia, Edisi IV. Cetakan VIII; Jakarta: PT. Gramedia Putaka Utama, 2014. 
Durkheim, Emile. The Elementary Forms of Religious Life.London: Allen \& Unwin, 1974.

Dhavamony, Mariasusai. Fenomenologi Agama. Yogyakarta: Kanisius. 1995.

Djamas, Nurhayati. “Varian Keagamaan Orang Bugis Makassar”. Dalam Muhlis dan Kathryn Robinson (ed) Agama dan Realitas Sosial. Ujung Pandang: Lephas, 1985.

Erwin.Aliran Kebatinan (Analisis Historis dan Kultur) dalam Jurnal Keislaman dan Peradaban "Hadharah". Volume IV; Padang: Institut Agama Islam Negeri Padang (PPs IAIN), September 2004.

Gazalba, Sidi. Pengantar Kebudayaan Sebagai Ilmu. Jakarta: Pustaka Antara, 1998.

Geertz, Clifford. Tafsir Kebudayaan. Cet. Ke-4;Yogyakarta: Kanisius, 2016.

Hamid, Abu.Selayang Pandang Uraian Tentang Islam dan Kebudayaan Orang Bugis-Makassar di Sulawesi Selatan dalam Bugis - Makassar dalam Peta Islamisasi di Indonesia. Ujung Pandang: LP3M IAIN Alauddin, 1982.

Hamid, Pananrangi, et all., ed. Pembinaan Budaya Dalam Lingkungan Keluarga Daerah Sulawesi Selatan. Ujung Pandang: Departemen Pendidikan dan Kebudayaan-Proyek Penelitian dan Pembinaan Nilai-Nilai Budaya Sulawesi Selatan, 1993.

Hefner, Robert W. Geger Tengger; Perubahan Sosial dan Pekelahian Politik. Yogyakarta: LkiS, 1999.

Husken, Frans. Masyarakat Desa Dalam Perubahan Zaman: Sejarah Diferensiasi Sosial di Jawa 1830-1980. Jakarta: Gramedia, 1989.

Ibrahim.Nilai-Nilai Budaya Lokal pada Masyarakat Muslim Silanggaya Kecamatan Tinggimoncong Tombolo Pao Kabupaten Gowa (Suatu Tinjauan Teologi Sufistik), Laporan Hasil Penelitian. Makassar: Lemlit UIN Alauddin, 2013.

Ilham.Muh.Integrasi Islam dengan Budaya Lokal (Kearifan Lokal dalam Ungkapan Makassar dan Relevansinya dengan Pendidikan Islam) di Kabupaten Gowa.Disertasi Pascasarjana UIN Alauddin Makassar, 2013.

Iqbal, Muhammad Zafar. Kafilah Budaya. Jakarta: Penerbit Citra, 2006.

Jainuri, Achmad. Ideologi Kaum Reformis: Melacak Pandangan Keagamaan Muhammadiyah Periode Awal. Surabaya: LPAM,

Kaelan.Filsafat Bahasa Semiotika dan Hermeneutika. Edisi I; Yogyakarta: Paradigma, 2009.

Katu, Mas Alim. Kontektualisasi Ajaran Datok Tiro, Apliled Research untuk Penguat Perda Keagamaan Bulukumba dalam "Resume Penelitian" Makassar: t.t.

Mattulada.Islam di Sulawesi Selatan dalam Agama dan Perubahan Sosial. Taufiq Abdullah (ed). Jakarta: Rajawali Press, 1983. 
Muhtmar, Shaff. Masa Depan Warisan Luhur Kebudayaan Sulsel. Makassar: Pustaka Refleksi, 2007.

Muhammad, Abu al-Fath bin Abd.al-Karīm al-Syahrastānī, al-Milal wa al-Nihal, jilid I Bairūt: Dār al-Kutub al-Ilmiah, t.th

Mulyana, Deddy, ed., Komunikasi Antara Budaya. Cet. VII; Bandung: PT. Remaja Rosdakarya, 2003.

Mulder, Niels. Kebatinan dan Hidup sehari-hari Orang Jawa. Jakarta: Gramedia, 1983).

Putra, Heddy Ahimsa. Fenomenologi Agama: Pendekatan Fenomenologi untuk Memahami Agama, Vol. 20 dalam Jurnal Penelitian Walisongo, Nomor 2. 2012.

Permana, R. Cecep Eka. Kearifan Lokal Masyarakat Badui dalam Mitigasi Bencana. Jakarta: Wedatama, 1910.

Poerwanto, H. Kebudayaan dan Lingkungan Dalam Perspektif Antropologi. Yogyakarta: Pustaka Pelajar, 2000.

Raharjo, Mudjia, Dasar-dasar Hermeneutika Antara Intensionalisme dan Gadamerian. Yogyakarta: Ar-Ruzz Media, 2000.

Rahman, Nurhayati. "Syariat Islam dan Sistem Panngaderreng" (Makalah yang disajikan pada seminar International dan Festival Kebudayaan (Empat Abad Islam Melembaga di Sulawesi Selatan) yang dilaksanakan kerjasama Pusat Kajian Timur Tengah dengan Devisi Ilmu-ilmu Sosial dan Humaniora Pusat Kegiatan Penelitian Unhas dengan Pemerintah Kota Makassar: 2008.

Rasdiyanah Amir, Andi. Integrasi Sistem Pangngaderreng (Adat) dengan Sistem Syariat sebagai Pandangan Hidup Orang Bugis dalam Lontarak Latoa, "Disertasi". Yogyakarta: PPS IAIN Sunan Kalijaga, 1995.

Rudyansjah, Tony. Kekuasaan, Sejarah dan Tindakan; Sebuah Kajian Tentang Lanskap Budaya.Jakarta: Rajawali Press, 2009.

Said, Nurman.MasyarakatMuslim Makakssar: Studi Pola-Pola Integrasi Sosial antaraPagamadenganMuslim Sossorang. Jakarta: Badan Litbang dan Diklat Kementrian Agama RI. 2009.

Saifuddin, Achmad F. Konflik dan Integrasi: Perbedaan Paham dalam Islam di Indonesia. Jakarta: Rajawali, 1985.

Suhardi. "Agama dan Dimanika Masyarakat” Silabus Mata Kuliah Paskasarjana Antropologi UGM. Yogyakarta: Paskasarjana Antropologi UGM, 2016.

Sutiyono.Benturan Budaya Islam: Puritan dan Sinkretis. Jakarta: Kompas Media Nusantara, 2010.

Sumaryono, E. Hermeneutika Sebuah Metode Filsafat, Yogyakarta: Kanisius, 1999. Syam, Nur. Mazhab-Mazhab Antropologi. Yogyakarta: Pelangi Aksara, 2007.

Tim Pustaka Phenix, Kamus Besar Bahasa Indonesia, Cet. V; Jakarta: PT Media Pustaka Phoenix, 2010. 
Thohir, Ajid. Perkembangan Peradaban di Kawasan Dunia Islam: Melacak Akar-akar Sejarah, Sosial, Politik, dan Budaya Umat Islam. Cetakan I; Jakarta: PT. RajaGrafindo, Persada, 2004.

Tsing, Ann Laura. Di Bawah Bayang-Bayang Ratu Intan; Proses Marjinalisasi Pada Masyarakat Terasing. Jakarta: Yayasan Obor Indonesia, 1998.

Tylor, Edward B. Primitive Culture. Leiden: E.J. Brill, 1998.

Universitas Islam Negeri Alauddin Makassar.Pedoman Penulisan Karya Tulis Ilmiah; Makalah, Skripsi, Tesis, Disertasi, dan Laporan Penelitian.Edisi Revisi, Cetakan Pertama; Makassar: UIN Alauddin Press, 2013.

Van Peursen, CA. Strategi Kebudayaan. Yogyakarta: Kanisius, 1988.

Zainuddin, Musyair. Minangkabau dan Adatna; Adat Bersendi Syarak, Syarak Bersendi Kitabullah. Yogyakarta: Ombak, 2013. 